\title{
On Native Origin of the American Indians
}

\author{
Tianxi Sun \\ Environmental Protection Bureau, Suzhou, China \\ Email: 18913505350@163.com
}

How to cite this paper: Sun, T.X. (2016) On Native Origin of the American Indians. Open Journal of Applied Sciences, 6, 636-647. http://dx.doi.org/10.4236/ojapps.2016.69061

Received: August 19, 2016

Accepted: September 20, 2016

Published: September 23, 2016

Copyright (@) 2016 by author and Scientific Research Publishing Inc. This work is licensed under the Creative Commons Attribution International License (CC BY 4.0).

http://creativecommons.org/licenses/by/4.0/

(c) (i) Open Access

\begin{abstract}
There have been controversies over differing opinions in the source of the American Indians. In this paper, the writer criticized the so-called classical theory that the remote ancestors of the American Indians entered America from Asia through the Bering Straits 14,000 20,000 years ago, worn their "clothes" and carried kindling during the late Paleolithic, no matter how by "boat" across the Bering Sea or by foot through a "Bering Land Bridge" which might once link up Asia and North America during glacial period; and independently proposed a new hypothesis that American Indians might be originated from the Western Rift Valley of North America. On the basis of locus distribution of American ancient human's remnants, the writer pointed out that American ancient humans might be first originated at Yukon Territory of Canada within the Western Rift Valley of North America (the Basin \& Range Province), and then migrated south ward (Yukon Territory $\rightarrow$ Mojave Desert $\rightarrow$ Mexico $\rightarrow$ Peru $\rightarrow$ Chile). Moreover, American Indians would have long been a presence for 40,000 years, or even 100,000 200,000 years in the American continents. So far, the logical basis which American Indians came from Asia 14,000 20,000 years ago was crushed, and derived two inferences: 1) American Indians might be originated from the Western Rift Valley of North America; 2) Only the Eskimo might be the mover eastward from Asia, because of their gene B.
\end{abstract}

\section{Keywords}

American Indians, Native Origin, Genetics of Human Blood, Rift Valley, Controversy

\section{Introduction}

The American Indians was the indigenous inhabitants of Americas and a sum name of all natives in South and North America before European colonists intruded into Americas in the end of the fifteen-century. There have been controversies over differing opinions in the source of American Indians.

In despite of this, Archaeologists and Anthropologists usually considered that the 
remote ancestors of the American Indians entered America from Asia through the Bering Straits 14,000 20,000 years ago [1], no matter how by "boat" across the Bering Sea or by foot through a "Bering Land Bridge" which might once link up Asia and North America during glacial period [2] [3].

The bases of this classical theory above, summing up by me, would have 8 items as follows:

1) The characteristics in Anthropology seemed to be looked alike each other between the American Indians and the Asian, especially Mongolian Spots [4] and Shovel Incisors [5] [6].

2) In Siberia, North China and North America, the late cultural things left behind by the deceased especially "wedge-shaped stone-cores" during the Old Stone Age were similar [7]; the primitive societies in those places all took tiger as their totem.

3) The "Diego" sub-blood group found in some American Indians tribes among Venezuelan bushes was later widely also discovered in Northeast Asia [8] [9].

4) The JC Virus in the bodies of American Indians coincided with that of the Japanese [10].

5) The bacterium in the bodies of American Indians might be traced back to Siberia [11].

6) America could not be a place of humans originating, the evidences as following: There existed only the lowest monkeys in America [12]; the earliest activity of the mankind in America was only 12,000 years ago [2].

7) A study on mtDNA had showed that almost the whole American Indians would be the descendants of 4 women who came from Asia into America about 20,000 years ago [13].

8) It made possible that the Asian entered Americas from Asia because of "the Bering Land Bridge" between Asia and North America [2] [4].

However, the classical theory above would be wrong, I think. Here, I'll criticize it point by point.

\section{Analysis}

\subsection{About Anthropology Characteristics}

Many scholars had put the American Indians under Mongolian Race [14] [15] according to cinnamon skin, black hair with straight and sturdy [4], especially shovel incisors with higher frequency [5] [6] and the blue-black Mongolian Spots outside their baby's sacrum [4].

In fact, even though the scholars who held this classical opinion such as Academician WU Rukang at Institute of Vertebrate Paleontology and Paleoanthropology, Chinese Academy of Sciences, also had observed "an extreme difference" between the American Indians and the Asians: "The Mongoloid fold in the upper eyelid, as one of the characteristics of the yellow race, but hardly found in the American Indians" [15]. An anthropologist of Mainz University also felt puzzled for it why an evolution of only 20,000 years produced so outstanding genetic variation if the hypothesis that the Asians en- 
tered into Americas could be established [16]?

It should be indiscreet if races could be judged only by Anthropometrics. The morphology did not reflect the adoption precisely [17]. Someone had said that the American Indians might just like the Europeans in the light of having no Mongoloid fold, having raised middle-high bridge of the nose, as well as having undulant hair and welldeveloped whisker in some Indian tribes [14].

As to Mongolian Spots and shovel incisors, they might appear in all races, only having higher or lower rates of appearance [6]. These two bodily characters could not be considered as decisive foundations for judging humans races, just like we would not look upon Bushman in Africa as one of the Mongolian Races although they also have Mongoloid folds [6], and just like we would not regard some Negro tribes as Russians although their faces much like Caucasians [18]. The Europeans might be similar to the Jew, the former would belong in Aryan ancestry and the latter Semite descent, however [18].

The reality which the American Indians bears a striking resemblance to the Yellow Race of Asia, I think [19] [20], could be explained in biology, i.e., the so called "astringency evolution"-although several animals had been completely different each other thousands of years ago, they could converge into similar species now [21]. Genetic similarity be not equal to affinity [22]. It's necessary to avoid taking analogous structures as homology [17]. In fact, many different animals owned similar organs (Figure 1) [23].

\subsection{About Ancient Cultural Hangovers}

In 1930's, west archaeologists put a possibility that there perhaps existed cultural connections between Asia and Americas in prehistoric age. After this, many microlithic remains found within wide regions of East Asia and Northwest America. On these grounds, some scientists considered that there existed a so-called " $U$-shaped Cultural Band in North Pacific Region" [24]. Thus, they reached a conclusion that Siberia or Mongolian Desert was the native place of the American Indians [7].

Even worse, someone affirmed that the American Indians should be from North China according to the same type and the same processing method of over 200 sphenoid

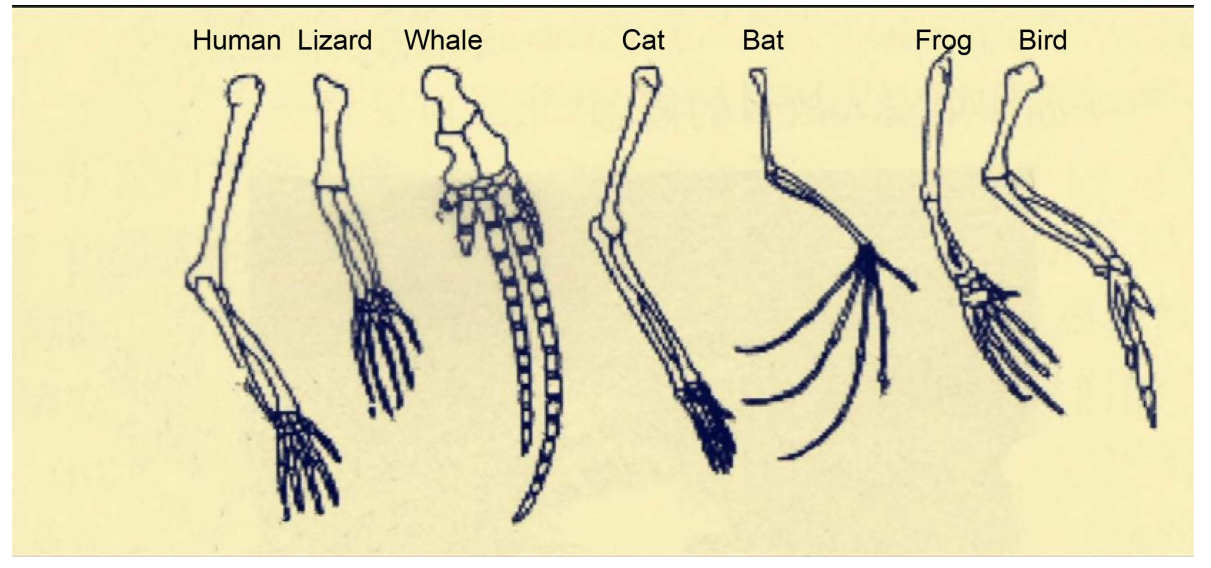

Figure 1. Analogous organs (sizes out of proportion). 
stone cores unearthed from Hu-Tou-Liang village, Sang-Gan river valley district of North China during 1972-1974 [7].

Maya's 13 ahau katuns showed that ecliptic was divided into 13 parts; this would be much similar to the ecliptic pattern with 13 heads found in Mali [25]. Moreover, ceremonies and witchcrafts of the American Indians in Middle America, praying for rain, broadly in line with that of the people in West Africa [25]. How could we say the American Indians were originated from West Africa?

The calendar of Mexico seemed to be similar to that of Hinduism; and there were rather analogy in poses of God and Juggernaut between Mexico and Hinduism [25]. How could we say the Mexico Indians originated from India or the India's Indians came from Mexico?

As for totem, the primitive societies in Siberia, North China and North America all took tiger as their totem. Hence someone made tiger totem as one of the bases of the hypothesis that the American Indians might have been originated from Asia. It would be wrong however. As an example, the "Tlingit tribe" in North America used to worship totems, their totems were crow, wolf, whale, vulture, bear, dolphin, shark, frog, goose, sea lion, owlet, salmon and so on, but no tiger. So was the Yellow Race of Asia. In the ancient China, the classical totems were dragon, snake, bird and tiger [26]. The tiger totem only was one of the totems. So, the theory of tiger totem above may be lamely inferred.

\subsection{About Diego Sub-Blood Type}

The "Diego" sub-blood group found in American Indian tribes among a Venezuelan jungle in 1955 also later discovered widely within Northeast Asia. Accordingly, some scientists considered that they had found out a testimony in hematology that the American Indians should be the descendant of the immigrants from East Asia [8] [27].

In fact, in race specificity blood types except "Diego", there were very remarkable and essential differences between the American Indians and the Asians [27]:

- In 1918, Mr. \& Mrs. Hirszfeld noticed that there were some blood type differences among races. For instance, as for gene B of blood type, it is extinct in the American Indians whereas universal in the Asians [17] [28]. Please look at Figure 2 [29] and Table 1. It must point out that the Eskimo had gene B [30]. Thus, only the Eskimo but the American Indians might enter Americas from Asia.

- $\mathrm{B}_{\mathrm{w} 54}$ was used to be called "the Yellow Race Antigen". But, $\mathrm{B}_{\mathrm{w} 54}$ of the American Indians was just equal to zero. By contrast, $B_{w 54}$ of the Chinese was 4.71 and that of the Japanese 7.3 [27].

- JK gene frequency in the Brazilian Indians was equal to 0.2453 whereas that all the Asians were zero (see Table 2) [27].

- Frequency of the Lewis blood type in the Asians was very high. For example, Le (a+) in the Asians was from $20.81 \%$ to $28.48 \%$ [27], whereas very rare in the American Indians [31]. 


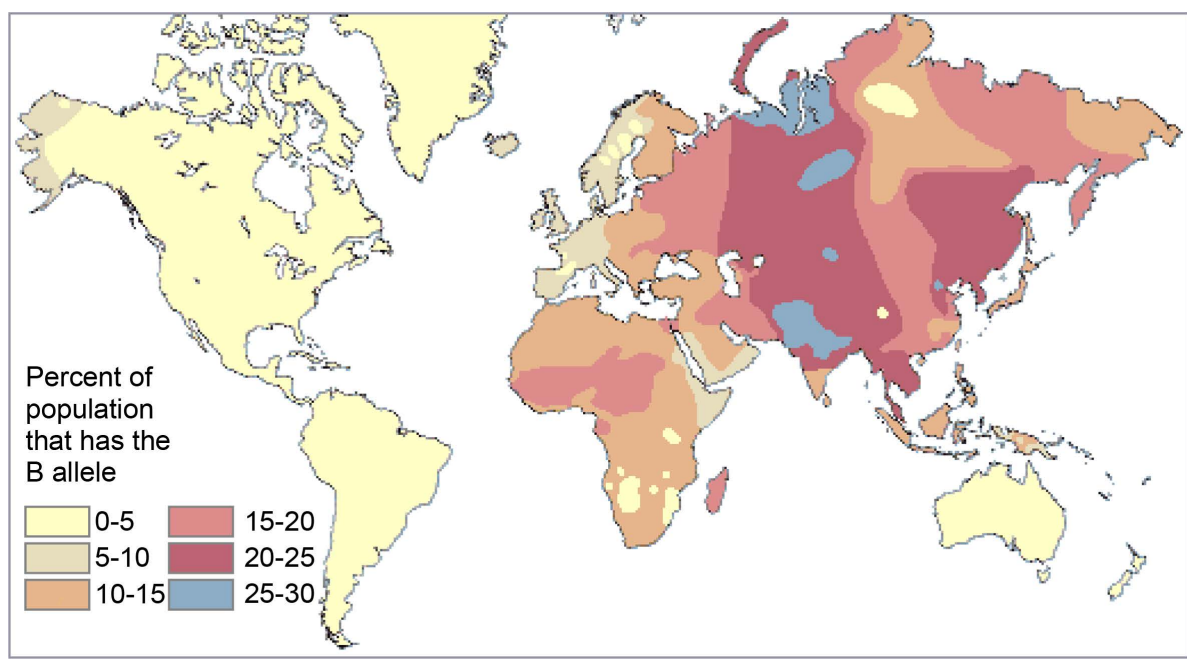

Figure 2. Distribution of the B type blood allele in native populations of the world.

Table 1. HLA-B locus gene frequency $\left(\times 10^{2}\right)$.

\begin{tabular}{ccccccccc}
\hline & $\mathrm{B}_{13}$ & $\mathrm{~B}_{37}$ & $\mathrm{~B}_{\mathrm{w} 47}$ & $\mathrm{~B}_{\mathrm{w} 54}$ & $\mathrm{~B}_{\mathrm{w} 55}$ & $\mathrm{~B}_{\mathrm{w} 58}$ & $\mathrm{~B}_{\mathrm{w} 59}$ & $\mathrm{~B}_{\text {blank }}$ \\
\hline The American Indians & 0 & 0 & 0 & 0 & 0 & 0 & 0 & 0.1 \\
The Han nationality & 9.45 & 0.4 & 0.1 & 4.71 & 0.6 & 4.05 & 0.1 & 11.47 \\
The Japanese & 2.0 & 0.5 & 0.2 & 7.3 & 2.9 & 0.9 & 2.1 & 12.1 \\
\hline
\end{tabular}

By Zhao Tongmao (1987) [27].

Table 2. JK gene distributed frequency in some populations.

\begin{tabular}{ccc}
\hline Population & Person numbers for investigation & JK gene frequency \\
\hline The Han nationality (Shanghai, China) & 200 & 0 \\
The Uighur nationality & 221 & 0 \\
Overseas Chinese (New York) & 103 & 0 \\
The Dong nationality (Guangxi, China) & 201 & 0 \\
The Japanese & 100 & 0.2453 \\
The Brazil Indians & 88 &
\end{tabular}

By Zhao Tongmao (1987) [27].

Just because of these differences above, the anthropologist S. M. Garn affirmed that it was just the American Indians that appeared as a fully isolated state in genetics [32]!

\subsection{About JC Virus}

It was reported that the JC Virus in the bodies of American Indians coincided with that of the Japanese. Accordingly, some scientists considered that the American Indians should be originated from Asia [10].

I do feel puzzled why didn't you reach such a direct conclusion that the American Indians originated from Japan? However, could you first prove that the ancient hu- 
mans had already existed on Japanese archipelago 20,000 years ago? In fact, the history of the oldest Japanese natives was less than 12,000 years old [33].

\subsection{About Bacterium}

Dr. Mack Achteman of Germanic Marks Plank Infection Biology Research Institute et al. found in 2003 [11] that human's enteron had been infected by 7 different pyloric Spiro-bacteria. The bacterium had infected half our humans, mostly through our home members. They considered that the activities of our ancestors were hardly revealed because of humans' very complex genes; however, the activity track of our ancestors since 10,000 years could have been gotten through studying the genes of humans' parasites. For instance, the bacterium in the bodies of American Indians might be traced back to Siberia [11].

For this view, I'll only raise two points: the first, Dr. Brian Sprat of London Empire Institute had challenged it. He doubted a jumble of crowd whether could provide correct messages for migration of humans. He considered that this view might be the most dependable only to an isolated crowd such as Polynesian [11]. The second, the time limit this view showed was "since 10,000 years", which had been incompatible with "before 20,000 years" stipulated by the classical theory of the Asians spanned the Bering Bridge to North America, thus not suiting to explain the source of the American Indians.

\subsection{About Human Originated in Americas}

In Paleocene Epoch and Eocene Epoch, 70 million 40 million years ago, inchoate primates widely dispersed over the world. Their fossils were very rich except South America, Australia and Antarctica. The oldest fossil of primate in Americas only was Purgatorius unearthed under Eastern Montana of USA in 1965 [2] [34]. Moreover, any fossil of anthropoid would have not been found in Americas so far. Hence, some scholars declared that American continents should not be a source place of humans [12].

Such conclusion needs to be further investigated, I think. The reasons are as follows:

- Now that the Western Rift Valley of North America (also called "the Basin and Range Province" in geology) which were formed about two billion years ago [35], were pregnant firstly in the world with bird [36], mammalian [37], dinosaurian [38] and primate [39] etc., why could not they also independently breed out anthropoid and the ancients? In fact, living things on our Earth were closely related to rift valleys all over the world [40], and their mechanisms [41], as well as our Human had been originated from Continental Rift Valleys [42], all had been proved.

- Although fossils of anthropoid haven't yet been unearthed in the Americas, we can't jump rashly to a conclusion that Americas have no any this kind of fossils. This might only be a question to take time or a question so few researchers had excavated in Rift Valleys of Americas. In 1927, paleoanthropologists Prof. Yang Zhongjian et al. predicted that the Asia might be one of the origin places of mankind although at that time there hadn't been found any fossils of anthropoid in Asia. And in fact, the fossils of Homo erectus later unearthed in Yuanmou County within Panxi Conti- 
nental Rift had testified this remarkable foresight.

- Their conclusion mentioned above might be arrived too hastily. And the like, some scholars [43] had affirmed that the time aborigines appeared in Australia would be $4000 \sim 5000$ years ago; but only one year later, their view was overthrown by a new discovery that the earliest time the humans appeared in Australia should be at least 50,000 years ago [2]!

It must point out that people generally considered there didn't exist any humans until 10,000 20,000 years ago in Americas. The bases of this view were as follows:

- The carbon-14 dating to some stone-lances and stone-arrowheads unearthed from New Mexico in 1920's [44].

- A dozen or less human skeletons lasted over 10,000 years unearthed from North America [45].

However, the view mentioned above had been vacillated even overthrown by a series of new findings recently:

- According to the carbon-14 dating, 26 stone-implements unearthed from Puerto Montt of the Central Chile had lasted 33,400 years [46] and the stone-implements unearthed from Peru had lasted over 40,000 years [25].

- Nucleus gene data had testified that the humans did settle down in Americas Continents at least about 30,000 years ago [47].

- Linguist Joanna Nichols of California University found that there were 150 language branches within Southern and Northern Americas and declared that the humans existed in Americas 40,000 years ago, according to much lengthy years needed for forming a new language branch [48].

- In September 2003, Prof. Silvia Gonzales et al. of UK found some footprints of humans near Puebla of Mexico within Rio Grande Rift valley (Figure 3) [49]; these

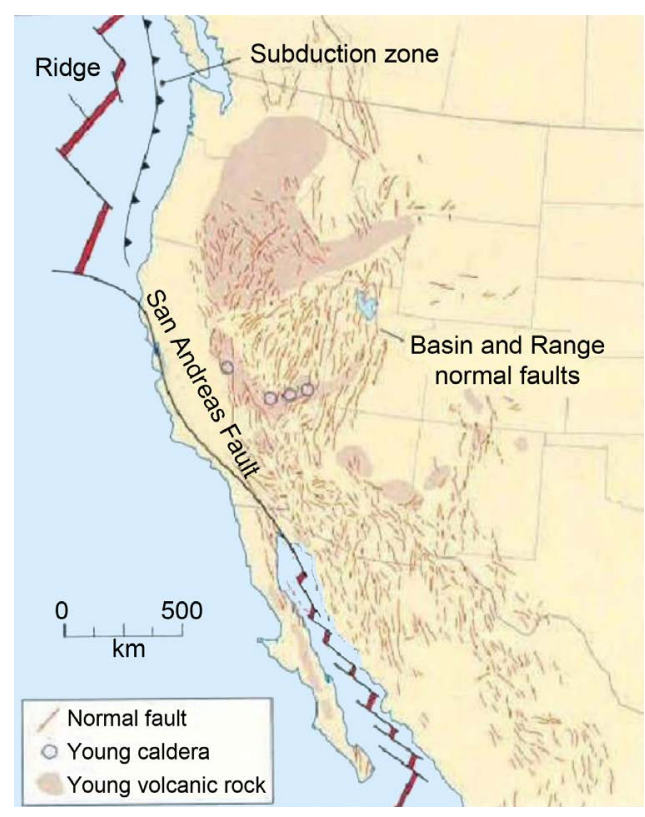

Figure 3. Geology map of western part of North America. 
footprints lasted 40,000 years [50]. The Rio Grande Rift is a rift valley extending north from Mexico, near El Paso, Texas through New Mexico into central Colorado.

- The unearthed cultural relics from near Yukon Territory of Canada and near Mojave Desert of USA (Figure 3) [49] were showed to have lasted 100,000 200,000 years, based on rigorous determinations [44]. The Mojave Desert stretches from the wedge-shaped Antelope Valley eastward across the Colorado River and into Arizona.

Locus distribution of American ancient human's remnants showed that: American ancient humans might be first originated at Yukon Territory of Canada within the Western Rift Valley of North America (the Basin \& Range Province), and then migrated southward (Yukon Territory $\rightarrow$ Mojave Desert $\rightarrow$ Mexico $\rightarrow$ Peru $\rightarrow$ Chile):

The unearthed cultural relics from near Yukon Territory of Canada and near Mojave Desert were showed to have lasted 100,000 200,000 years [49] $\rightarrow$ some footprints of humans near Puebla of Mexico where located in the Rio Grande Rift valley [49], these footprints lasted 40,000 years [50] $\rightarrow$ the stone-implements unearthed from Peru had lasted over 40,000 years [25] $\rightarrow 26$ stone-implements unearthed from Puerto Montt of the Central Chile had lasted 33,400 years [46].

In other words, American Indians would have long been a presence for 40,000 years, or even 100,000 200,000 years in the American continents.

Therefore, the classical theory which the remote ancestors of the American Indians entered Americas from Asia 15,000 20,000 years ago [1] would be wrong.

\subsection{About mtDNA}

In recent years, Professor Douglas Wallace at Emory University in Atlanta had studied changes in mitochondrial genes widely distributed in American Indian tribes among Southwestern United States, Central Americas as well as South Americas, and reached the following conclusion: almost all American Indians came to Americas from Asia across the Bering Strait about 20,000 years ago [51].

However, the following reasons why I do not agree with these conclusions are:

- Using mitochondrial method, Professor Wilson et al., at the University of California in 1967 got a conclusion that all the people in the world were the descents of a woman in Africa 200,000 years ago [52]; but Professor Brown at the same University obtained a conclusion using the same method was opposite: whether black, white or yellow, had similar genes 360,000 to 180,000 years ago, they all originated from Asia [53]. The same methodology, conclusions contrary, how far can the mitochondrial method be trusted?

- Despite more accurate information could be obtained in less sample by high-tech, but external disturbances and bias were easily emerged in this process. There were even some scientists skeptical of such an outcome.

- Some molecular biologists and paleontologists doubted the accuracy of "molecular clock". They considered that "molecular clock" was nothing but a pointer gene substantially random rate of change, rather than an absolute law; and gene evolutionary direction only a limited guide [54]. 
What is more, Paleontologist Aldo Bove at University of Michigan [55] considered unequivocally that Mitochondrial Bell did not exist. He said that mtDNA mutation rate would have almost certainly been influenced by extinction in the past. It changed quickly at some times; while on other periods, it did not change. The so-called Molecular Clock did not reflect this however. If the Molecular Clock still looked correct, purely because of even a broken clock was right twice a day!

\subsection{About Bering Land Bridge}

Archaeologists and Anthropologists usually considered that the remote ancestors of the American Indians entered America from Asia through the Bering Straits 15,000 20,000 years ago [1], no matter how by "boat" across the Bering Sea or by foot through a "land bridge" which might once connect Asia and North America [2] [3].

We probably would not oppose Professor Jia Lanpo's following view (3): it was unable to cross cold Bering Strait, if without the necessary equipment and conditions such as clothes and fire. So, the earliest crossing Strait action could not take place before the late Paleolithic.

As we all know, the Quaternary global glacial periods were divided into four stages: Gunz, Mindel, Riss and Wurm (aka Wisconsin). Of which, the third period of Wisconsin was 22,000 years ago [56], or 21,000 17,000 years ago [57], the second period of Wisconsin was 72,000 years ago (56), and the first period of Wisconsin 116,000 years ago [57]. So obviously, only the third period of Wisconsin could be consistent with the setting of Professor Jia Lanpo.

In view of scientific facts that world's ocean level during glacial periods decreased 100 or 150 meters and during interglacial periods rose tens of meters than modern times [56], i.e., only during glacial periods, the Bering Strait might have been exposed from ocean level to become so-called Bering Land Bridge, and therefore, only during the third period of Wisconsin, Asian prehistoric humans could have worn their "clothes" and carried kindling to cross Bering Land Bridge and finally to board the American continent.

In other words, American Indians could have not been appeared earlier than 21,000 years ago or 22,000 years ago, if the Land Bridge Immigrant Hypothesis could be established. But now, Americas have appeared much earlier indigenous mentioned above [25] [46] [49] [50]! What words can the Land Bridge Immigrant Hypothesis to say?

Someone may ask such question: Then, why could not they enter onto North America by boat during warm interglacial?

Speaking boats, ancient China's sea-transport might start from the late Neolithic. A boat paddle which had lasted about 7000 years unearthed in the seaside of East China [58]. A canoe unearthed at riverside of Seine River in France was said it had been lasted 4000 years [59]. Not yet seen a more ancient instance.

The written records about boat were even later. "Boat" concept first appeared in the Book of Changes between Yin and Zhou Dynasties which only started in 841 BC (1). Maritime traffic between the Mediterranean and the Americas, it started only from 400 
BC [55].

The paddle of 7000 years ago was one thing; whether the boat existed 40,000 years ago, for example, was another matter.

Prehistoric humans of $8000 \mathrm{BC}$ just learned how to tame animals, just learned how to collect and store grain [60], how we could imagine these humans 40,000 years ago be able to create boats across the sea? Yes, someone had explored a possibility that Chinese ships drifted into the coast of North America by strong winds or Kuroshio away, but that was in the fifth century $\mathrm{AD}$ [25]!

So far, the logical basis which American Indians came from Asia was crushed, and derived two inferences: 1) American Indians might be originated from the Western Rift Valley of North America; 2) Only the Eskimo might be the mover eastward from Asia, because of their gene $B$.

\section{Conclusion}

On the basis of locus distribution of American ancient human's remnants, the writer pointed out that American ancient humans might be first originated at Yukon Territory of Canada within the Western Rift Valley of North America (the Basin \& Range Province), and then migrated southward (Yukon Territory $\rightarrow$ Mojave Desert $\rightarrow$ Mexico $\rightarrow$ Peru $\rightarrow$ Chile). Moreover, American Indians would have long been a presence for 40,000 years, or even 100,000 200,000 years in the American continents. So far, the logical basis which American Indians came from Asia 14,000 20,000 years ago was crushed, and derived two inferences: 1) American Indians might be originated from the Western Rift Valley of North America; 2) Only the Eskimo might be the mover eastward from Asia, because of their gene B.

\section{References}

[1] Schurr, T.G. (2004) The Peopling of the New World: Perspectives from Molecular Anthropology. Annual Review of Anthropology, 33, 551-583. http://dx.doi.org/10.1146/annurev.anthro.33.070203.143932

[2] Wu, R.K. (1989) Paleoanthropology. Heritage Press, Beijing, 54-214. (In Chinese)

[3] Jia, L.P. (1991) When Did People Board the American Continent? Nature Discovery, 3, 12. (In Chinese)

[4] Zheng, B.Y. (1991) Mongolian Spots. UFO Research, 4, 13. (In Chinese)

[5] Sun, Q.Y. (1987) Yellow Race and Spade Incisors. Encyclopedic Knowledge, 10, 17. (In Chinese)

[6] Shao, X.Q. (1985) Anthropometric Manual. Shanghai Dictionary Publishing House, Shanghai, 279, 282-283, 363. (In Chinese)

[7] Liu, M.H. and Zhang, Z.H. (1982) A Brief History of American Indians. Sanlian Bookstore Press, 3-5. (In Chinese)

[8] Luo, X.J. and Chen, B.Y. (1989) Windfall of Blood Research. Knowledge Is Power, 9, 26-27. (In Chinese).

[9] Cui, H. (1987) About Diego Sub-Blood. Science Expo, 4, 3. (In Chinese)

[10] Anon. Washington Post. 1999-8-9. 
[11] Anon. Bacteria Help Human to Look for His Roots. Deutsche Presse-Agentur, 2003-3-6.

[12] Wu, R.K. (1976) The Origin and Development of Humans. Science Press, Beijing, 58. (In Chinese)

[13] Zhang, Y.Z. Xinmin Evening News, 1990-11-24. (In Chinese)

[14] Несмурх, М.Ф. (1963) Human Race. Shao, X.Q. Translate, Commercial Press, Shanghai, 29-32. (In Chinese)

[15] Wu, R.K. (1978) The Development History of Humans. Science Press, Beijing, 60-103, 248262. (In Chinese)

[16] Cai, F. (1983) Race and Environment. The Earth, 5, 17. (In Chinese)

[17] Ayala, F.J. (1990) Modern Integrated Theory of Evolution (K. Hu Trans.). Higher Education Press, Beijing, 239, 226-227, 114. (In Chinese)

[18] Darwin, C. (1982) The Descent of Man (G. D. Pan. Trans.). Science Press, Beijing, 2-234. (In Chinese)

[19] Sun, T.X. (1993) Did American Indians Originate from Asia (1)? UFO Research, 2, 18-19. (In Chinese)

[20] Sun, T.X. (1993) Did American Indians Originate from Asia (2)? UFO Research, 3, 13-14. (In Chinese)

[21] Belinsky, J. (1991) Darwin's Views on Alien Life. UFO Research, 4, 15. (In Chinese)

[22] Su, Y.Y. (1990) To Challenge the Theory of Evolution. The Fossils, 3, 10. (In Chinese)

[23] Tong, H.W. (2003) Demonstration of Biological Evolution. The Fossils, 1, 2-8. (In Chinese)

[24] Jia, L.P. and Chen, C. (1985) Prehistoric Cultural Ties between Asia and North America. The Pacific Ocean, Ocean Press, Beijing. (In Chinese)

[25] Luo, R.J. (1988) Mystery of the Chinese Discovered the Americas. Chongqing Publishing House, Chongqing, 7-81. (In Chinese)

[26] Chen, J.J. (1992) The Formation of Chinese Ethnic Totem Worship and Four Images Concept. Research of Natural Science History, 1, 9-21. (In Chinese)

[27] Zhao, T.M. (1987) Genetics of Human Blood. Science Press, Beijing, 363, 136, 145, 118, 116, 78. (In Chinese)

[28] Hirschfeld, L. and Hirschfeld, H. (1919) Serological Differences between the Blood of Different Races. The Lancet, 194, 675-679. http://dx.doi.org/10.1016/S0140-6736(01)48686-7

[29] Boyd, W.C. and Asimov, I. (1956) Races and People. American Anthropologist, 58, 946946. http://s155239215.onlinehome.us/turkic/63_Blood_Types/Blood_TypesEn.htm

[30] Anon (1981) History of Ancient World. People Press, Beijing, 2-11, 377-385, 97. (In Chinese)

[31] Race, R.R. and Sanger, R. (1975) Blood Groups in Man. 6th Edition, Blackwell Scientific Publications, Oxford, 323-349.

[32] Garn, S.M. (1961) Human Races. Thomas, Springfield.

[33] Liu, W. (1995) Talking about Dental Anthropology. The Fossils, 4, 13-17. (In Chinese)

[34] Pilbeam, D. (1983) The Rise of Humans-Introduction to Human Evolution. Science Press, Beijing, 20. (In Chinese)

[35] Chandler, V.W. (1990) Interpretation of Seismic Reflection, Gravity and Magnetic Datain the North American Continental Rift System. Marine Geology Renditions, 3, 51. (In Chinese)

[36] Le, W. (1989) Archaeopteryx’s “Throne” Had Been Shaken. The Fossils, 1, 31. (In Chinese)

[37] Hu, J.P. (1992) Newly Discovered Mammal Fossils. The Fossils, 1, 19. (In Chinese) 
[38] Ye, Y (Trans.) (1985) The Oldest Dinosaur Fossils. American Science News, 39, 4. (In Chinese)

[39] Sheng, Y.F. (Trans.) (1982) Problems of Earliest Primate Caused by Fossils. American Science News, 40, 1-2. (In Chinese)

[40] Sun, T.X. (2015) Close Relationship between Life Forms and Rift Valleys. Science Mars Journal, 2.

http://www.sciencemars.com/2015/12/close-relationship-between-living-things-and-rift-val leys/

[41] Sun, T.X. (2015) Mechanisms of Rift Evolution. Science Mars Journal, 2. https://www.sciencemars.com/2015/12/mechanisms-of-rift-evolution/

[42] Sun, T.X. (2004) Rift Evolutionism. Sichuan Science \& Technology Press, Chengdu. (In Chinese)

[43] Fang, G.Z. (1989) Can Forest Fire Control? Knowledge is Power, 9, 36. (In Chinese)

[44] Wang, S.X. (Trans.) (1987) Debris, Broken Bones, and the First American. Science News, 18, 18-19. (In Chinese)

[45] Wang, S.X. (Trans.) (1986) Archaeological Discoveries of Miami Ice Age. Science News, 11, 4. (In Chinese)

[46] Xu, X.M. (1989) Ancient Human Remains in South Africa. Knowledge is Power, 6, 43. (In Chinese)

[47] Spencer, W. (2004) Out of Africa-The Migration Epic of Human Ancestors. Du Hong Translate, Oriental Press. (In Chinese)

[48] Anon (1998) American Linguist Scholar Found That Humans Have Arrived in Americas 30,000 to 40,000 Years Ago. Associated Press.

[49] http://wenku.baidu.com/view/529d5cbdd5bbfd0a795673df.html?from=search

[50] Morse, S.A., Bennett, M.R., Gonzalez, S. and Huddart, D. (2010) Techniques for Verifying Human Footprints: Reappraisal of Pre-Clovis Footprints in Central Mexico. Quaternary Science Reviews, 2, 2517-2578

[51] Wallace, D.C., et al. (1992) Native American Mitochondrial DNA Analysis Indicates That the Amerind and the Nadene Population Were Founded by Two Independent Migrations. Genetics, 130, 153-162.

[52] Cao, Y. (1997) Multiple Distribution and Modern Human Origins. The Fossils, 1, 31-32. (In Chinese)

[53] Guo, Y.Z. (1983) The Human Race. Encyclopedic Knowledge, 9, 42.

[54] Ye, J.S. (Trans.) (1986) Molecular Clock Would Be Only a Limited Guide. Science News, 21, 20-21. (In Chinese)

[55] Marshall, E. (1990) Science beyond the Pale. Science, 2, 16.

[56] Weng, D.M. and Liu, H.L. (Trans.) (1986) Past and Future of the Climate. Meteorological Press, Beijing, 145-157. (In Chinese)

[57] Geological Society of China (1990) Earth Science Trend in Today's World-Chinese Scientists to Talk about the 28th International Geological Congress. Geology Press, Beijing, 158. (In Chinese)

[58] Fang, Z.F. (1981) Sailing America Three Thousand Years-Yin People Exploration across the Pacific Ocean. People Daily. (In Chinese)

[59] Qian, W. (1992) Canoe Photo 4,000 Years Ago. Science and Technology Daily. (In Chinese)

[60] George Newnes Ltd. (1964) Newnes World Atlas. Towers House, London, XXIV. 
Submit or recommend next manuscript to SCIRP and we will provide best service for you:

Accepting pre-submission inquiries through Email, Facebook, LinkedIn, Twitter, etc. A wide selection of journals (inclusive of 9 subjects, more than 200 journals)

Providing 24-hour high-quality service

User-friendly online submission system

Fair and swift peer-review system

Efficient typesetting and proofreading procedure

Display of the result of downloads and visits, as well as the number of cited articles

Maximum dissemination of your research work

Submit your manuscript at: http://papersubmission.scirp.org/

Or contact ojapps@scirp.org 